\title{
Gender Perception, Female Downgrading and Domestic Violence among Married Couples in Cross River State, Nigeria
}

\author{
Adadu, Paulinus M. A. Ph.D \\ Ecce Department, School Of Education, Cross River State College of Education, Akamkpa \\ Pmb 1171 Calabar, Cross River State - Nigeria; E-mail: paulinusadadu@gmail.com
}

Egbe, Alice O. A. M.Ed

Exams Department, Ministry Of Education Hqrs, Calabar, Cross River State - Nigeria

Undie, Josephine U. M.Ed

Ecce Department, School Of Ecce/Pes, College Of Education, Akamkpa, Cross River State - Nigeria

\section{Doi:10.5901/mjss.2015.v6n6s1p423}

\section{Abstract}

The study was designed to investigate gender perception, female downgrading and domestic violence among couples in Cross River State. the ext-post factor research design was used in this study. The major independent variables for the study were gender perception and female downgrading while domestic violence was dependent variable. Four research hypotheses were formulated to guide the research in this study. The sample for the study was 800 married couples, made up of 546 males and 254 females, a stratified random sampling and simple random sampling techniques were used to get the subjects for the study. The major instrument for the data collection was four-point likert type scale called Gender Perception and Female Domestic Violence Questionnaire (GPFDVQ). The responses obtained from the instrument were coded, scored and analyzed statistically; group means and standard deviation were calculated. The independent $t$-test and Pearson Product Moment Correlation were used to analyze the data. All the four hypotheses were tested at 0.5 level of significance based on the result of data analyzed. The following findings were made: (1) couples with negative self-concept, (2) there is a significant positive relationship between gender perception and the level of domestic violence among couples. The higher unfavourable perception of gender the higher the level of domestic violence among couples and (3) there is a significant negative relationship between female downgrading and the level of domestic violence among couples. Counselling implications as well as conclusion were made to make for a happy family life.

\section{Introduction}

Psychological scientists often divide the way man perceives the world into two distinct phases namely sensation and perception. Sensation focuses on how our sense organs respond to external stimuli such as lights, sounds etc. and how those responses are transmitted to the brain. Perception on the other hand, refers to the further processing of sensory signals in the brain that ultimately results in an internal representation of stimuli and the observer begins to think. Gender perception has to do with the processing of signals in the brain and interpretation leading to thoughts by males and females about one another (Gazzaniga and Healtherton, 2003, Akpama 2014).

For some time now gender perception, female down-grading and domestic violence among couples in Nigeria have increasingly become social menaces plaguing the family system. These problems constitute a lot of setback and poor family performance. Thus falling standard of family achievement of married couples is an important issue of concern to educationists, administrators and the general public at large.

In many families in the country there are several reports of acts of indiscipline such as drug abuse, prostitution, stealing, rioting and bullying, to mention a few. One is then forced to think and wonder what should be the factors influencing the increasing rate of female down-grading and domestic violence among couples. The aim of education is to bring about an all round development of an individual so that he becomes a useful member of the society to which he belongs. The school is one of the agents to bring about this desired change. However, with the present trend of indiscipline on the part of the married couples, the achievement of the aim is farfetched. 
Today, the position of women in contemporary Nigerian society is very much not better than that of 'a slave' especially, the illiterate women. An illiterate woman is often abused and exploited, while the educated is spitefully labelled 'an acada' and is often looked upon with suspicion by men who feel threatened.

In homes with married couples, men play the role of the traditional head of the family. Some men are tyrants; they rule and direct their wives in the manner a cattle herdsman does to his cattle. They often roar like thunder and administer physical blows on their wives at the slightest provocation and so the wives live in awe of them. Violence against women is an acceptable exercise of male's prerogative, a legitimate and appropriate way of relieving tension and condition of stress. To sanction female behaviour is just to enjoy a feeling of supremacy (Schlegal, 1977 Akwenabuaye et al, 20113), the women in our society are relegated to the kitchen and bedroom. These acts of violence, including using of abusive language and beating of women, are considered normal since some men believe that they are necessary to discipline and correct women because women, like children, need to be corrected.

Over the years, our country has allocated a substantial amount of money for the funding of education with the aim of producing responsible citizens generation and after generation. According to the National Policy on Education, one of the objectives is the inculcation of the right type of values and attitudes for the survival of the individual and the Nigerian society (Federal Republic of Nigeria, 2004).

Many writers and concerned educators have written much on the problem of domestic violence. A parliamentarian during debates on wife battering in Papau New Guinea commented, "Wife beating is an accepted custom. We are wasting our time debating the issue" (Bosmajian, 1972). In the same vein, in a response by the assistant to the public prosecutor in Peru when a student nurse reported being sexually molested by a police officer while in custody was asked "are you a virgin? "If you are not a virgin why do you complain? This is normal" (Baochaid 1999, Shahzadi et al 2012). Violence against women is therefore discrimination without frontiers. It is the physical maltreatment, exercising mental and physical torture and neglect of basic needs, abuse of right and sexual molestation of women.

Many empirical studies Hague (2009) and Palazzolo (2009) have been carried out on the factors influencing violence against women; such factors include poor feedings, poor home facilities, the leadership style of the husbands, attitude of wives to the family and others. The researchers concluded that when these influencing factors are erased the couples would be disciplined. However, it is observed that most couples in Cross River State still continue with their acts of violence in one way or the other despite the fact that they are educated couples with facilities to help them refrain from the acts of violence against women.

The purpose of this study is therefore, the need to arrest domestic violence among couples, by investigating into the social and psychological factors that influence domestic violence among women in order to help curb it or at least drastically reduce its incidence among couples in Cross River State, Nigeria.

\section{Hypotheses}

To investigate the problems of this study, four hypotheses were formulated:

(1) There is no significant difference in the level of domestic violence between couples with positive and negative self-concept.

(2) There is no significant influence of gender perception on the level of domestic violence among couples.

(3) Female downgrading has no significant effect on the level of domestic violence.

(4) There is no significant effect on the level of domestic violence among couples on their children's discipline behaviour.

\section{Methodology}

The research design implored for this study was ex-post facto design. The research was carried out in the senatorial district of Cross River State, Nigeria.

The population of the study consisted of estimated 8,000 married men and women. The sample for the study was 800 couples 546 males (67.5\%) and 245 females (32.5\%). The instrument used for this study was designated Gender Perception and Female Domestic Violence Questionnaire (GPFDVQ). The researchers' instrument was constructed for couples to assess the attitude of society towards gender perception and female downgrading and domestic violence among couples. points.

It was a forty item for point likert type scale with scoring key as Strongly Disagree (1) point to Strongly Agree (4)

In order to ascertain whether the research instrument is measuring what it purports to measure; GPFDVQ was 
given to experts in measurement and evaluation of Cross River University of technology. The experts arrived at $85 \%$ agreement using the non-empirical armchair method. After a critical examination of the instrument with regard to its relevance, adequacy and domestic violence, the experts identified some errors and flaws in phraseology, grammar, and mechanics in the items. The necessary modifications were made which confirmed the face validity of the instrument.

To ascertain the reliability of the research instrument; a pilot study was conducted with an equivalent group, that is, subjects that have the same characteristics with the main study population. The GPFDVQ was administrated to 50 respondents who were randomly selected from the study populations but were not part of the main study. Two weeks after the first administration, the questionnaire was re-administered to the same respondents. The reliability of the instrument was determined by subjecting the data obtained from the pilot study to statistical analysis. Test-rest reliability coefficient ranged from 0.7 to 0.94 .

The results portrayed the reliability of the instrument. The standard for reliability coefficient of 50 would suffice in early stages of researches on any psychological construct based on the results of the statistics. It was observed that the reliability estimate for each-scale met the criterion of internal consistency. The instrument was therefore regarded as reliable to be adopted for the study.

\begin{tabular}{|c|c|c|c|c|c|}
\hline Variables & No. of items & Testing & $\mathrm{X}$ & Sd & Rff \\
\hline Domestic violence & 15 & $\begin{array}{l}1^{\text {st }} \\
2^{\text {nd }}\end{array}$ & $\begin{array}{l}36.18 \\
37.04\end{array}$ & $\begin{array}{l}2.56 \\
2.59\end{array}$ & 0.94 \\
\hline Gender perception & 6 & $\begin{array}{l}1^{\text {st }} \\
2^{\text {nd }}\end{array}$ & $\begin{array}{l}16.19 \\
16.56\end{array}$ & $\begin{array}{l}2.41 \\
2.28\end{array}$ & 0.93 \\
\hline Children domestic violence & 4 & $\begin{array}{l}1^{\text {st }} \\
2^{\text {nd }}\end{array}$ & $\begin{array}{l}14.30 \\
14.90\end{array}$ & $\begin{array}{l}1.28 \\
1.22\end{array}$ & 0.86 \\
\hline Self concept & 5 & $\begin{array}{l}1^{\text {st }} \\
2^{\text {nd }}\end{array}$ & $\begin{array}{l}15.14 \\
15.75\end{array}$ & $\begin{array}{l}1.20 \\
1.28\end{array}$ & .86 \\
\hline Perception by others & 5 & $\begin{array}{l}1^{\text {st }} \\
2^{\text {nd }}\end{array}$ & $\begin{array}{l}16.96 \\
17.62\end{array}$ & $\begin{array}{l}1.34 \\
1.32\end{array}$ & 0.78 \\
\hline Female down grading & 5 & $\begin{array}{l}1^{\text {st }} \\
2^{\text {nd }}\end{array}$ & $\begin{array}{l}15.76 \\
16.62\end{array}$ & $\begin{array}{l}1.35 \\
1.50\end{array}$ & 0.84 \\
\hline
\end{tabular}

The test-retested reliability coefficient as shown in the table above ranges from 0.78 to 0.94 . They are rendered very high justifying the reliability of the instruments for use in the main study.

\section{Hypothesis Testing}

\subsection{Hypothesis 1}

In the null form, this hypothesis posited that there is no significant difference in the levels of domestic violence between couples with positive and negative self-concept.

The independent t-test analysis was used to test this hypothesis. The result of the analysis is presented in table 1.

Table 1: Independent t-test analysis of difference in the level of domestic violence among couples with positive and negative self-concept

\begin{tabular}{|c|c|c|c|c|}
\hline Self concept & $\mathbf{N}$ & $\mathrm{X}$ & SD & $t$ \\
\hline Negative & 300 & 37.08 & 3.26 & \\
\hline Positive & 500 & 36.57 & 3.42 & $2.13^{*}$ \\
\hline Total & 800 & 36.67 & 3.83 & \\
\hline
\end{tabular}

The result of the analysis revealed a significant t-value of 2.13 . This value was found to be greater than the critical t-value and with 798 degrees of freedom.

The null hypothesis was thus rejected. This result implies that couples' self-concept has a significant influence on their involvement in domestic violence. Observation of table 1 reveals that coupes with negative self-concept had a higher mean level of domestic violence amongst them $(X=37.08)$ than couples with positive self-concept. These differences were found statistically using the independent t-test analysis. 
This null hypothesis speculated that there is no significant influence of gender perception of the level of domestic violence. Using the Pearson Product Moment Correlation Coefficient, this hypothesis was tested. The result of the analysis is displayed in Table 2.

Table 2: Pearson product movement correlational analysis of influence of gender perception on the level of domestic violence among couples $(\mathrm{N}=800)$

\begin{tabular}{|c|c|c|c|c|}
\hline Variables & $\begin{array}{l}\sum X \\
\sum y\end{array}$ & $\begin{array}{l}\sum x^{2} \\
\sum x y^{2}\end{array}$ & $\sum X$ & rxy \\
\hline $\begin{array}{l}\text { Gender perception (x) } \\
\text { Level of domestic violence among couples (y) }\end{array}$ & $\begin{array}{l}12361 \\
29408\end{array}$ & $\begin{array}{l}199155 \\
1090084\end{array}$ & 549066 & 0.54 \\
\hline
\end{tabular}

The result showed that there is a significant positive relationship between gender perception and the level of domestic violence among couples $(r=0.54 ; \mathrm{df}=798 ; p<.05)$. The result is significant because the calculated $r$-value of 0.54 was found to be far above the critical r-value of 0.0692 given .05 alpha levels and with 798 degree of freedom. The null hypothesis was thus rejected and the research hypothesis upheld.

The positive relationship obtained in this result implies that the higher the unfavourable perception of gender the higher the level of domestic violence among couples. Conversely, the lower the unfavourable perception of gender the lower the level of domestic violence among couples.

\subsection{Hypothesis 3}

In the null form, this hypothesis stated that female downgrading has no significant effect on the level of domestic violence among couples. To test this hypothesis; the Pearson Product Moment Correlational analysis was done. The result of the analysis is presented in Table 3 .

\begin{tabular}{lcccc}
\hline Variables & $\sum \mathbf{X}$ & $\sum \mathbf{x}^{2}$ & & \\
& $\sum \mathbf{y}$ & $\sum \mathbf{x y}^{2}$ & $\sum \mathbf{X}$ & rxy \\
\hline Female downgrading $(\mathrm{x})$ & 12389 & 199794 & 549066 & \\
Level of domestic violence among couples $(\mathrm{y})$ & 29408 & 1090084 & & $-0.38^{*}$ \\
${ }^{*} \mathrm{P}<.05 ; \mathrm{df}=798 ;$ critical $\mathrm{r}=0.0692$. & & & &
\end{tabular}

The result of the analysis that there is a significant negative relationship between female down-grading and the level of domestic violence among couples $(r=-0.36 ; \mathrm{df}=798 ; \mathrm{p}<.05)$. The null hypothesis was rejected because the calculated $r$ value of -0.36 was found to be far greater than the critical value of 0.0692 at 0.05 alpha level and with 789 degree of freedom. This result implies that female downgrading has a significant influence on the level of domestic violence among couples.

The negative sign in the result means that the higher the level of perceived female downgrading the lower the level of domestic violence among couples. On the other hand the lower the level of perception of female downgrading the higher the level of domestic violence among couples.

\section{Results}

(1) Couples with negative self-concept are more violent than couples with positive self-concept.

(2) There is a significant positive relationship between gender perception and the level of domestic violence among couples. The higher the unfavourable perception of gender, the higher the level of domestic violence among couples.

(3) There is a significant negative relationship between female downgrading and the level of domestic violence among couples.

(4) There is a significant negative relationship between parental level of domestic violence and children's discipline behaviour. 


\section{Discussion of the Research Findings}

\subsection{Self-concept and domestic violence among couples}

Analysis of relevant data here shows that there is a significant impact of self-concept on the level of domestic violence among couples. Couples with negative self-concept are found to be more violent than those with positive self-concept. These findings is consistent with Chaunhan (2003); Cohen (1976). These findings are not surprising. The finding can be attributed to excessive worries, tension, economic dependence, frustration and poverty among couples with negative selfconcept. It is to this end that Chauhan (1985, Eunju, 2007) argues that poverty of parents and lack of money to fulfil the legitimate needs of children led directly to certain kinds of frustration. This, no doubt can aggravate domestic violence. Individuals with low or negative self-concept suffer from inordinate amount of anxiety (Herbert, 1977 and 2006) no wonder Cohen (1976) states that when a person fails to gain recognition and a favourable self-image he will tend to withdraw from particular activity and strive to devalue its worth. Thus, couples with negative self-concept have a sense of interpersonal distance between them based on mistrust or lack of understanding of feelings. They are aggressively prone, easily irritated and insolent.

On the contrary, couples whose image of themselves is a good one tend to have such desirable qualities as good adjustment low level of anxiety and self-confidence. They react to domestic problem with a sense of maturity and understanding. Hence, they experience less domestic violence. In support of these facts, Herbert (1977 and 2006) maintained that a reasonable agreement between the self-concept (myself as I am) and the concept of the ideal self (myself as I would like to be) is one of the most satisfaction in life. Therefore couples with positive self-concept are welladjusted people and have high self-regards.

\subsection{Gender perception of female downgrading and couples level of domestic violence}

The result on gender perception of female downgrading and level of domestic violence among couples indicates a high and a significant positive relationship between the two variables. This means that the higher the unfavourable perception of gender, the higher the level of domestic violence among couples and vice versa. The finding implies that gender perceptions have a common variable with the level of domestic violence among couples. If couples (husband and wife) view themselves as equal and work together with trust and understanding, there will be less family violence. According to Nkawonso (1994, Enuju, 2007) women and men are equal before God, as God created and valued them as unique individual persons. Unfortunately many husbands see themselves as superior to their wives so the wives must take orders from them any resistance will meet with unfavourable consequences - violence which can take various dimensions.

Thus, the way couples view each other may increase or reduce the level of domestic violence. The findings of this study are in line with the work of Essien (1994) who discovered a significant relationship between gender perception and domestic violence among couples.

He concluded that violence against women and children seems to have become culturally accepted as part of daily life and that the blood guild concept was socialized into the women's thought pattern right from childhood. In many African traditional societies, girls perceive themselves as being sub-standard.

There are differences in societal treatment of men and women both socially and culturally. These differences first begin within the family where the girl is treated as a domestic servant and the young boy is encouraged to be aggressive and to go out to play. Women are viewed differently from men. In a family where the husband has unfair advantage over the wife simply because he is a man, violence will manifest as a result of injustice. Another plausible explanation to the present study finding is the way the society, discriminate against women. In our society, the husband has the right to claim damages from a wife on grounds of adultery. Also some women find it difficult to drop their husband's names after divorce because society would term them loose and irresponsible (Nakowombe, 1994, Agbaje, 2011).

In many families, husbands still frown at the continuous delivering of female children by their wives. They threaten them with divorce or marrying of a second wife so as to have a male child. According to Nwachukwu (1996, Agbaje, 2011) if the family feels they have too many daughters, they start to express anxiety, failure and insecurity. This of course can create very serious crises in the family (Akwenabuaye et al 2013).

\subsection{Parental level domestic violence and children discipline behaviour}

Parental level of domestic violence found to correlate significantly $(r=-0.23 ; P<.05)$ with children's discipline behaviour. 
The correlation is however, negative. This finding implies that the higher the level of domestic violence among couples, the lower the children's level of discipline behaviour, and the lower the level of domestic violence among couples, the higher the level of discipline behaviour of children. In other words where there is less violence the level of indiscipline is low and where there is more violence the level of indiscipline is high. This study result leads credence to Ukeji (1993, Agbaje, 2011) who argued that family violence emotionally damages children, causing fear, anxiety, guilt and stress. They can resort to joining bad companies for security reasons and therefore indiscipline behaviours such as smoking, alcohol and drug abuse in order to keep pace with the stress of life. Also juvenile delinquency is common among children from homes troubled with violence.

Another area of domestic violence, which has great impact on the moral behaviour of children is sexual violence. This ranges from rape by husband on their wives and by men outside the house. In families where there are sexual harassments of women by men, the children grow, imbedding it as a moral process in life. This must have contributed to the growing trend in sexual harassment of females in educational institutions, offices and during athletic competitions without fear. Female circumcision or genital mutilation is another area of sexual violence against women. This is done with the aim of denying women sexual pleasure and controlling female promiscuity. But unfortunately, the effect is manifested in sexual dissatisfaction by the female circumcised and so is forced to move from one man to another in research of who will give her the satisfaction. Thus leading to promiscuity that the society wants to stamp out.

Children in homes plagued by violence stand the risk of suffering from malnutrition due to poor feeding by parents. This nonchalant attitude of the parents can lead the children to stealing in order to feed properly. No wonder that Ukeji (1993, Hilton et al 2014) maintains that children in homes troubled with violence are physically abused or seriously neglected at a rate, say 15 times more often than other children and so they are often hurt "indirectly". It is not gain saying that children that are exposed to domestic violence by parents in forms of beating of the women slapping, kicking, using of abusive language can copy such behaviour and exhibit such as indiscipline behaviour among their peers. Thus, the extent to which couples are involved in domestic violence determines the level of children's indiscipline behaviour (Agbaje, 2011 and Akpama, 2014).

\subsection{Implication for counselling}

From the result of the finding, the following recommendations are being made:

1. There is need for spouses (couples) to learn techniques for coping with and resolving the inevitable conflicts of family life by peaceful means other than and coercion.

2. The family, the church and society should ensure sexual equality for the prevention of wife beating (domestic violence). No sex should be viewed as being superior to the other. All children irrespective of their sexes should be encouraged to grow and develop maximally. Parental expectation, parent-child interaction and all other aspects of socialization should not be differentiated according to the sex of the child.

3. The implicit toleration of domestic violence that has been entrenched through statutory and common laws, attitude of the police prosecutors and judges should be eliminated from the criminal justice (judiciary) system.

4. The government should ensure full employment for all men and women in the labour market at wage levels that are consistent with societal standards and there should be welfare scheme for the unemployed.

\section{Conclusion}

There is the existence of negative and positive gender perception, female downgrading and domestic violence among couples in Cross River State of Nigeria.

It is hoped that the findings and counselling implications, if carefully followed will reduce domestic violence and other related problems among married couples in Cross River State and the country at large.

\section{References}

Adams, A. and Sullivan, B. G. (2008). Department of the scale of Economics Abuse: Violence Against Women: 14(5) 563-588.

Agbaje, A. A. and Eyo, U. E. (2011). "Counselling Psychologist Skills

Agu, S. N. (1985). Duties and responsibilities of the principals. Nigerian Journal of Guidance and Counselling. 2, 30-32.

Akpama, E. G. (2014). "Parental Perception in Secondary school in Cross River State, Nigeria". Himalayan Journal of Sociology and Anthropology.

Akwenabuaye, Undeukwo Okorie Kalu, Ushie Mike Anake, Osonwa. Roy (2013). Happiness Family Planning Behaviours and Decision 
Making Among Couples in Cross River State, Nigeria. International Journal of Learning and Development. Albert, Olawale (1996). Women and Urban Violence in Kano, Nigeria - Ibadan: Spectrum Books.

Andrews, I. O. (1991). Economic effects of the war upon women and children in Great Britain - New York: Oxford University.

Balogun, L. (2002). Why Does He Do That? Inside the Minds of Angry and Controlling Men. Berkely Books http:/booksgodle.com/books.

Barnett, O. (2001). Why Battered Women Do Not leave, part 2: External Inhibiting factors, social support and internal inhibiting factors: Trauma, violence and Abuse 2 (1) 3-35.

Beerios, D. (1991). Domestic violence: Risk Factors and Outcomes: Western Journal of Medicine: 17(2) 133-142.

Bem, S. L. and Ben, DJ. (1970). Case study of a Conscious Ideology. Training the Women to know her place. Belomont: Brooks.

Bernard, H. W. \& Fullmer, D. W. (1977). Principles of Guidance (2nd Ed.) Hargers Town, New York: Harper \& Row Publishers.

Bojowoye, O. (1986). Guidance services: A study of the views of the Teacher of Secondary Schools in Kwara State of Nigeria, Nigerian Journal of Counselling and Development, 1, 51-61.

Dickson, Alex, Aslin Jennings and Carry Koop (2015). Domestic Violence and Football in Glassgow are reference points relevant? Oxford Bulletin of Economics and Statistics.

Educational Reforms and Innovations in Nigerian Primary

Eunju Lee (2007). "Domestic Violence and Risk Factors Among Korean Immigrant Women in the United States". Journal of Family Violence.

Herbert (2006). Early Adolescence 11 to 14 or 15 years Clinical Child and Adolescent Psychology.

Hilton, Jeanne M. and Stephen L. (2014). Child Spirituality Aging of Older Latinos' Counselling and Values.

Schools". International Journal of Academic Research.

Shahzadi, Nirghat Kalson Qureshi, Mian Bagar Hussain and Islam, Madika (2012) "Effect of Domestic Violence on Women Psychology in Pakistan" Language in India. 